\title{
RECOMBINANT THERMOTOLERANT PHYTASE PRODUCED IN E.COLI
}

\author{
Altynay Seitkhanovna Axambayeva ${ }^{1}$, Alexander Vyacheslavovich Shustov ${ }^{2}$
}

\begin{abstract}
Phytic acid (myo-inositol hexakisphosphate) and its salts (phytates) are the major storage form of phosphorus in plants. Monogastric animals including hogs, poultry, and fish cannot utilize phytates as a source of phosphorus unless they are enzymatically destroyed with exogenous enzyme - phytase. Phytases are added to fodder in ever increasing dosage to improve utilization of plant-derived phosphorus because this reduces dependence of farms on inorganic fodder phosphates. Because of technological considerations, feed phytases have to withstand elevated temperatures $\left(60-80^{\circ} \mathrm{C}\right)$, which are used during preparation of fodder. Enzymatic feed additives are becominutesg of high demand in Kazakhstan, and development of domestic technologies for production of agricultural enzymes is an ongoing challenge to the country's biotechnology.
\end{abstract}

Objectives: To develop a system for recombinant expression of industrially important thermotolerantphytase and confirm activity and thermal stability of the recombinantly expressed enzyme.

Methods: De novo gene synthesis, expression of 6xHis-tagged protein in E.coli, immobilized metal affinity chouromatography, biochemical tests for activities of phosphatase and phytase.

Results: Thermotolerantphytase was produced in E.coli using recombinant expression system. The obtained enzyme had phosphatise activity (hydrolyzed p-nitrophenyl phosphate) and phytase activity (hydrolyzed sodium phytate). The recombinant phytase tolerated increase of incubation temperature up to $70^{\circ} \mathrm{C}$ and demonstrated increase in activity towards phytate with increase in the reaction temperature in the range $30^{\circ} \mathrm{C}-70^{\circ} \mathrm{C}$.

Conclusion: Described gene and expression system have prospects of utilization in development of pilot industrial production of phytase in the country.

UDC Classification: 577.2; 604.4; 577.15, DOI: http://dx.doi.org/10.12955/cbup.v3.631

Keywords: Phytase, Nov9x, enzyme, feed additive, recombinant expression, thermal stability

\section{Introduction}

In plants, the predominutesant storage form of phosphorus is phytic acid salts (myo-inositol hexakisphosphate), which account for 50-80\% of the total phosphorus content in cereals and legumes (Harland \& Morris, 1995). Monogastric animals including hogs, poultry, and fish cannot digest phytates due to low concentration of enzyme (phytase) in their digestive tract (Selle, Ravindran, Caldwell, \& Bryden, 2000). During the past two decades, industrially produced phytases have been added to farm animal diets to enhance the utilization of phosphorus (Luo et al., 2007). In general, phytase is added to feed before it is pelleted at elevated temperatures $\left(60-80^{\circ} \mathrm{C}\right)$, thus the enzyme needs to survive elevated temperatures. Besides retaining activity after incubation at high temperatures, the thermotolerantphytase should have optimal activity at physiological temperatures

$\left(37^{\circ} \mathrm{C}\right)$.

Phytases are phosphatases cleaving ester bonds in the inositol phosphates (Konietzny \& Greiner, 2002). Phytases were found in more than 200 species of microorganisms and plants, but vertebrates to day produce endogenous phytase (Liu, Rafiq, Tzeng, \& Rob, 1998). Enzymes from actinomycetes and fungi (e.g. Peniophoralycii 6-phytase or Aspergillusniger 3-phytase) were the first commercialized phytases for feed additives (Vohoura \& Satyanarayana, 2003). Phytases are classified into six classes according to structure of the active center: histidine acid phosphatases (HAP), cysteine phytases (CPhy), purple acid phosphatases (PAP), and beta-propeller phytases (BPP) (Mullaney \& Ullah, 2003). Depending on the optimal $\mathrm{pH}$, phytases are divided into acidic and alkaline phytases $(\mathrm{Oh}, \mathrm{Choi}$, Park, Kim, \& Oh, 2004). Acidic phytases demonstrate the highest activity at $\mathrm{pH} 2,5-5,5$. Acidic phytases include bacterial

\footnotetext{
${ }^{1}$ Altynay Seitkhanovna Axambayeva, laboratory assistant, National Center for Biotechnology, Astana, Kazakhstan, altynai@bk.ru

${ }^{2}$ Alexander Vyacheslavovich Shustov, PhD, head of laboratory, National Center for Biotechnology, Astana, Kazakhstan, shustov@biocenter.kz
} 
and fungal representatives. Their aminuteso acid sequences have a conserved motif containing a histidine residue, which is involved in a nucleophilic attack (Wyss et al., 1999). Bacterial acid phytases demonstrate greater specific activity compared to fungal counterparts. Among all studied phytases, the highest specific activity was shown for E. coli phytaseAppA and CitrobacterfreundiiphytaseAppA. Disadvantage of natural bacterial phytases is their low thermal stability. Thermal stability of bacterial enzymes can be significantly improved by the enzyme engineering. Engineered mutant of the E.coliphytaseAppA with the name "Nov9x" has extremely attractive combination of high activity in stomach and impressive thermal tolerance. We aimed to produce the recombinant thermostablephytase Nov9x in E.coli and study its activity at elevated temperatures.

\section{Materials and methods}

\section{Genetic engineering}

Gene for Nov9x was synthesized de novo using construction PCR. Sequence of the Nov9x gene was designed in silico to be codon-optimized for expression in E.coli. Constructed DNA fragment contains $1236 \mathrm{bp}$ of the phytase-specific sequence (without signal peptide for periplasmic export), and hexahistidine tag and linkers for cloning into expression vector. The synthetic DNA fragment was cloned into pGEM-T and subjected to bidirectional sequencing to verify the constructed sequence. The Nov9x gene was transferred into pET32 expression plasmid (Novagen) by cloning into NcoI-XhoI restriction sites. E.coli strains BL21(DE3) was transformed with the resulting plasmid pET32/Nov9x.

\section{Small-scaled experiment to determinutese phytase accumulation in induced culture}

Expression strain was inoculated into $100 \mathrm{ml}$ of LB medium with ampicillin (100 ug/ml). When culture reached $\mathrm{OD}=0.6$, the IPTG was added to $0.2 \mathrm{mM}$. At time points of 1 hour, 2 hours, 4 hours, 6 hours, and 14 hours. Samples $(10 \mathrm{ml})$ of culture were taken, and bacteria were pellet by centrifugation. Bacterial pellet was resuspended in $1 \mathrm{ml}$ of $\mathrm{HN}$ buffer ( $20 \mathrm{mM}$ HEPES pH 7,5; $150 \mathrm{mMNaCl}$ ), and bacteria were disrupted by sonication (for pulses by 30 seconds at maximum power). Probes (15 ul) of sonicate were investigated in SDS-PAGE.

\section{Production of recombinant phytase}

The BL21(DE3)/pET32/Nov9x was inoculated into night culture (5 $\mathrm{ml}$ of LB medium with ampicillin, $100 \mathrm{ug} / \mathrm{ml})$. On the next day, $100 \mathrm{ul}$ of night culture were transferred into $200 \mathrm{ml}$ of LB medium with ampicillin $(100 \mathrm{ug} / \mathrm{ml})$. Culture was incubated at $37^{\circ} \mathrm{C}, 150 \mathrm{rpm}$, for 14 hours. Bacteria were pelleted by centrifugation, resuspended in water, and re-pelleted. The pellet was suspended in $10 \mathrm{ml}$ of lysozyme lysis buffer (20\% sucrose; $20 \mathrm{mM}$ HEPES pH 7,5; 5 mMEDTA; 0,1\% Triton X100). To the suspension, lysozyme was added to $1 \mathrm{mg} / \mathrm{ml}$, DNAse I - $10 \mathrm{ug} / \mathrm{ml}$,RNAse - $100 \mathrm{ug} / \mathrm{ml}$, and PMSF - 0,2mM. Suspension was incubated for 1 hour at room temperature. Suspension was sonicated (10 pulses for 20 seconds, with 3-minutes pauses between pulses). Bacterial debris was removed by centrifugation (10000 rpm, 20 minutes). The supernatant was subject to metal affinity chromatography (IMAC).

\section{Purification of recombinant phytase by IMAC}

Clarified supernatant was loaded onto column His GraviTrap (GE Healthcare) charged with Ni2+ ions. $3 \mathrm{ml}$ of wash buffer (50 mM HEPES pH 7.0; $300 \mathrm{mMNaCl} ; 20 \mathrm{mM}$ imidazole) was passed through the column. Proteins were eluted with buffers with increasing concentration of imidazole (100-300 mM). Elution buffers contained $50 \mathrm{mM}$ HEPES pH 7.0, $300 \mathrm{mMNaCl}$, and imidazole $(100 \mathrm{mM}, 200 \mathrm{mM}$, or $300 \mathrm{mM}$ ). Eluted proteins were investigated in SDS-PAGE and tested for the enzymatic activity.

\section{Tests for enzymatic activity of phytase}

Two tests were employed to measure the enzymatic activity of phytase. One method employs the natural substrate for phytase - phytate. Sample (50 ul) of phytase was added to $616 \mathrm{ul}$ of $0.25 \mathrm{M} \mathrm{NaAc} \mathrm{pH} 5.5$. 
The solution was preincubated at selected temperature for 5 minutes, and then $333 \mathrm{ul}$ of $10 \mathrm{mM}$ water solution of sodium phytate (Sigma, P8810) was added. The mixture was incubated at selected temperature for 15 minutes. Then, the amount of released phosphate was measured using a colorimetric reaction with vanadium-molybdenum reagent. For the preparation of the vanadiummolybdenum reagent, $0.6 \mathrm{~g}$ of ammonium metavanadate $\left(\mathrm{NH}_{4} \mathrm{VO}_{3}\right)$ was dissolved in $440 \mathrm{ml}$ of water; then, $560 \mathrm{ml}$ of $25 \%$ nitric acid and $25 \mathrm{~g}$ of ammonium molybdate $\left((\mathrm{NH} 4)_{2} \mathrm{MoO}_{4}\right)$ were added. The probe containing free phosphate was mixed with $1.5 \mathrm{ml}$ of the vanadium-molybdenum reagent. The resulting mixture was incubated at $37^{\circ} \mathrm{C}$ for 1 hour. Any precipitates were removed by centrifugation, and the absorbance of the supernatant was measured at $415 \mathrm{~nm}$.

The second test utilizes the ability of phytase to hydrolize a non-natural colorigenic substrate pnitrophenyl phosphate (PNPP). This method is quick and less tedious than the test with the natural substrate. Sample (50 ul) of phytase was added to $850 \mathrm{ul}$ of $0.25 \mathrm{M} \mathrm{NaAc} \mathrm{pH} \mathrm{4.5.} \mathrm{The} \mathrm{solution} \mathrm{was}$ preincubated at $37^{\circ} \mathrm{C}$ for 5 minutes, and then $100 \mathrm{ul}$ of water solution of PNPP ( $\left.4 \mathrm{mM}\right)$ was added. The reaction was incubated at $37^{\circ} \mathrm{C}$ for 15 minutes. Then, $100 \mathrm{ul}$ of $10 \mathrm{M} \mathrm{NaOH}$ was added. The resulting yellow color was quantified using absorbtion measurement at $410 \mathrm{~nm}$. In all tests, imidazole elution buffer was used as a dummy probe to produce spectrophotometer blanks.

\section{Results}

Figure 1 presents SDS-PAGE (10\%) of proteins accumulating in culture of the BL21(DE3)/pET32/Nov9 $x$ in the presence of chemical inducer IPTG. The expected product of recombinant expression, fusion protein Trx-Nov9x, has a molecular mass of $63.4 \mathrm{kDa}$.

Figure 1: SDS-PAGE of proteins accumulating in induced culture. Lanes: 1) before addition of IPTG; 2) 1 hour after addition of IPTG; 3) 2 hours; 4) 4 hours; 5) 6 hours; 6) 14 hours. Lane M - protein marker. Arrow points at band of the recombinant expression product.

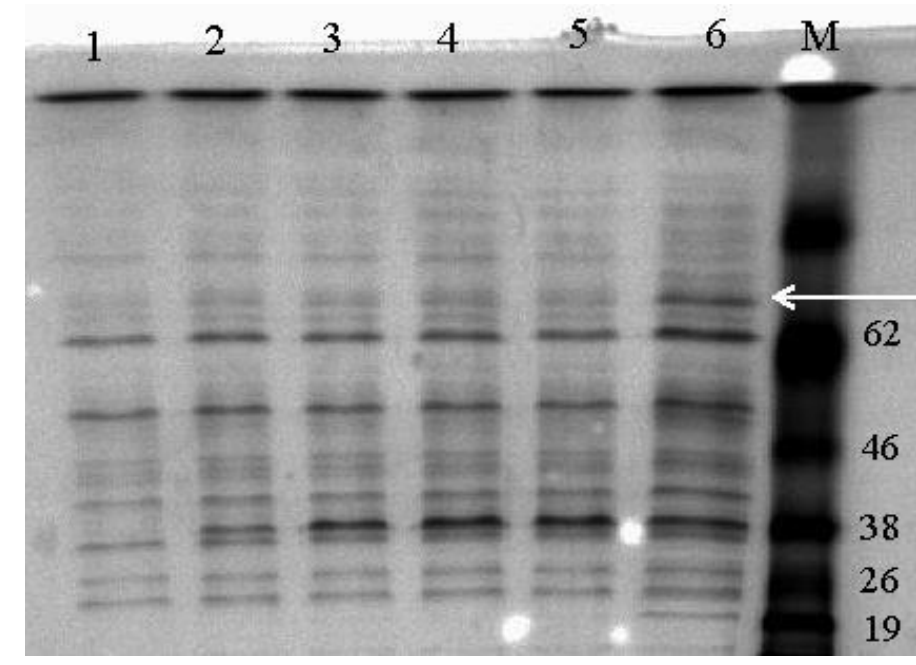

Source: Authors

Figure 2 presents sequence of the synthesized Nov9x gene. DNA fragment was synthesized using the two-rounds PCR. Primers for the first round PCR (designated as P1-P32 in Figure 2) alternate in order Sense-Antisense-Sense-Antisense. A mixture of primers P1-P32 was PCR-amplified (all primers in equal concentration, concentrations of individual primers sum up to $100 \mathrm{pM} / \mathrm{ul}$ ) using the high precision Phusionthermophilic polymerase. Reaction mixture of the first round amplification was used as template for the second round PCR with primers PNco + PXho (Figure 2). 


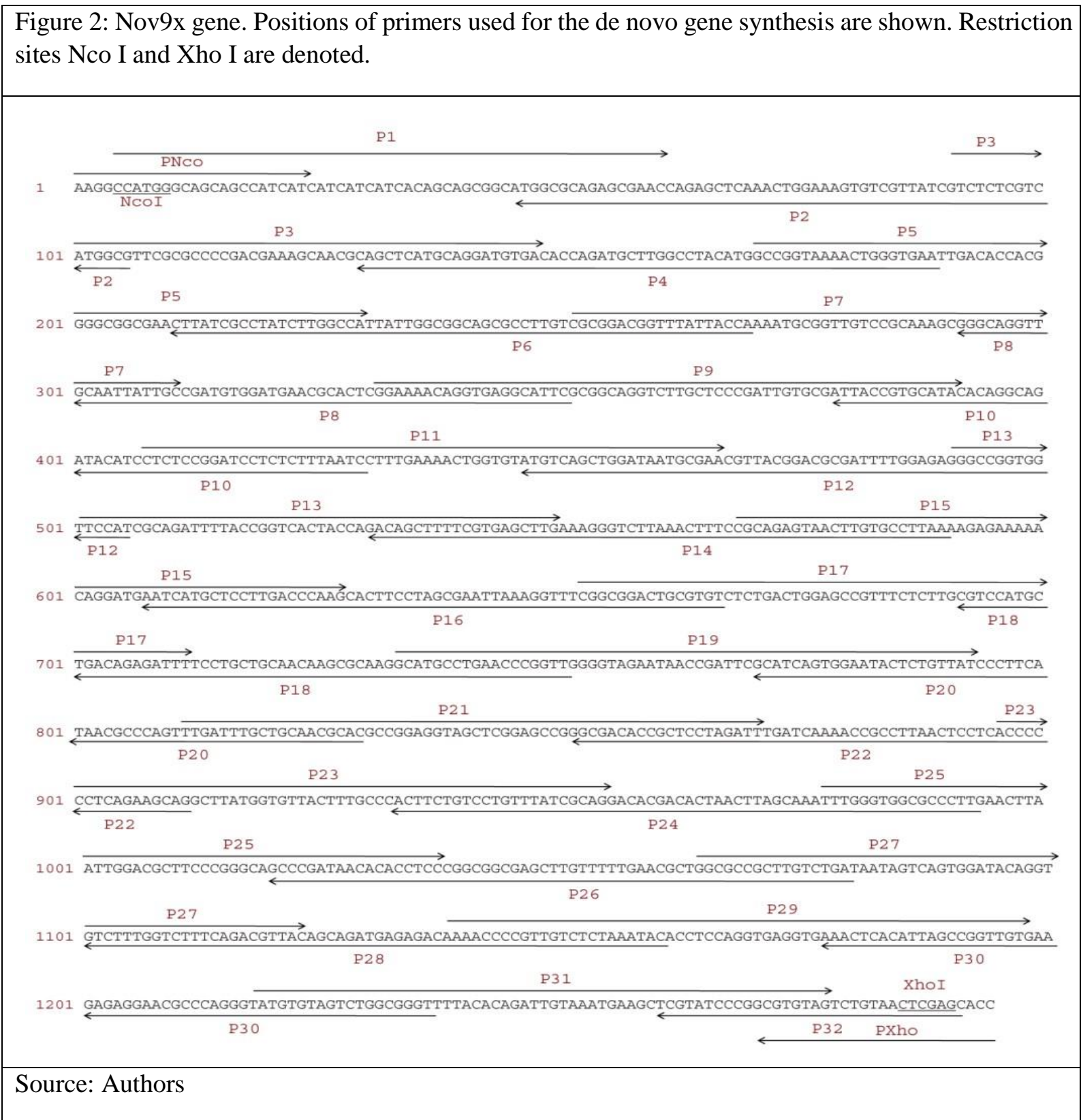

Figure 3 presents results of purification of the recombinant protein using IMAC. SDS-PAGE (15\%) shows that protein with the expected molecular mass $(63.4 \mathrm{kDa})$ elutes in a range of imidazole concentrations of 100-300 mM. Some contaminating proteins with lower $\mathrm{Mw}$ are also visible suggesting that single round IMAC is not sufficient to obtain pure recombinant phytase.

Figure 4 presents results of testing for phosphatase activity in the same samples for which the protein content is presented in Figure 3. This test was conducted with the PNPP substrate.

Combined samples of protein eluted into buffers with 100-300 mM imidazole was used to confirm thermostability of the obtained recombinant phytase. This test was performed with sodium phytate as substrate. Combined sample was mixed with sodium acetate buffer $\mathrm{pH} 5.5$ and sodium phytate. The reaction mixture was incubated at various temperatures in the range of $30-80^{\circ} \mathrm{C}$. It appeared that activity of the Nov9x almost linearly depends on the temperature in the temperature range of $30-70^{\circ} \mathrm{C}$, and at $70^{\circ} \mathrm{C}$ enzymatic activity was two times higher than that at $30^{\circ} \mathrm{C}$ (Figure 5). 
Figure 3: Purification of the recombinant phytase using the immobilized metal affinity chouromatography, SDS-PAGE analysis of fractions. Lanes: M - protein marker; 1) clarified lysate; 2) flowthourough; 3) column wash (20 mM imidazole); 4) elution (100 mM imidazole); 5) elution (200 mM imidazole); 6) elution (300 mM imidazole). Arrow points at band of the recombinant expression product.

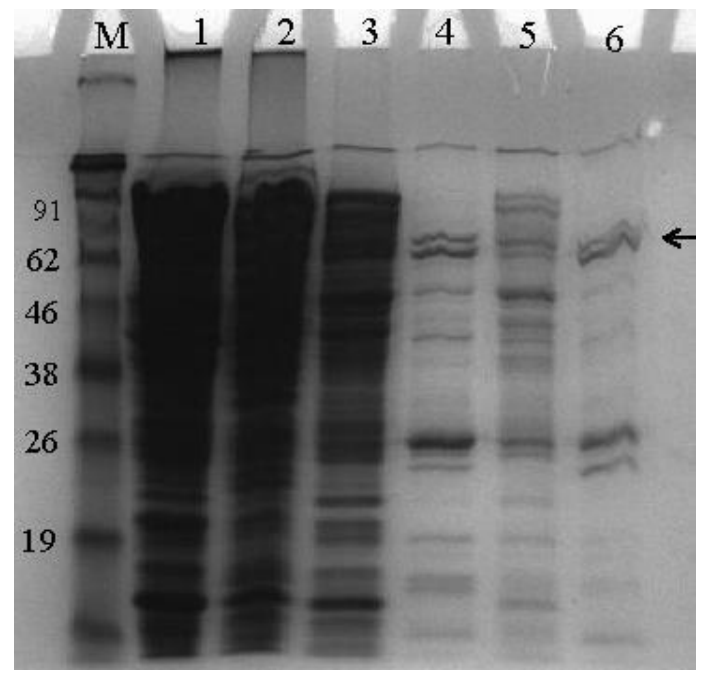

Source: Authors

Figure 4: Testing of phosphohydralase activity of phytase with the p-nitrophenyl phosphate (PNPP). Phytase has activity for removing of the phosphate group from PNPP. Samples collected during purification of the recombinant phytase were tested. Accumulation of the coloured product of the reaction (p-nitrophenol) is measured by absorbance of light at $410 \mathrm{~nm}$.

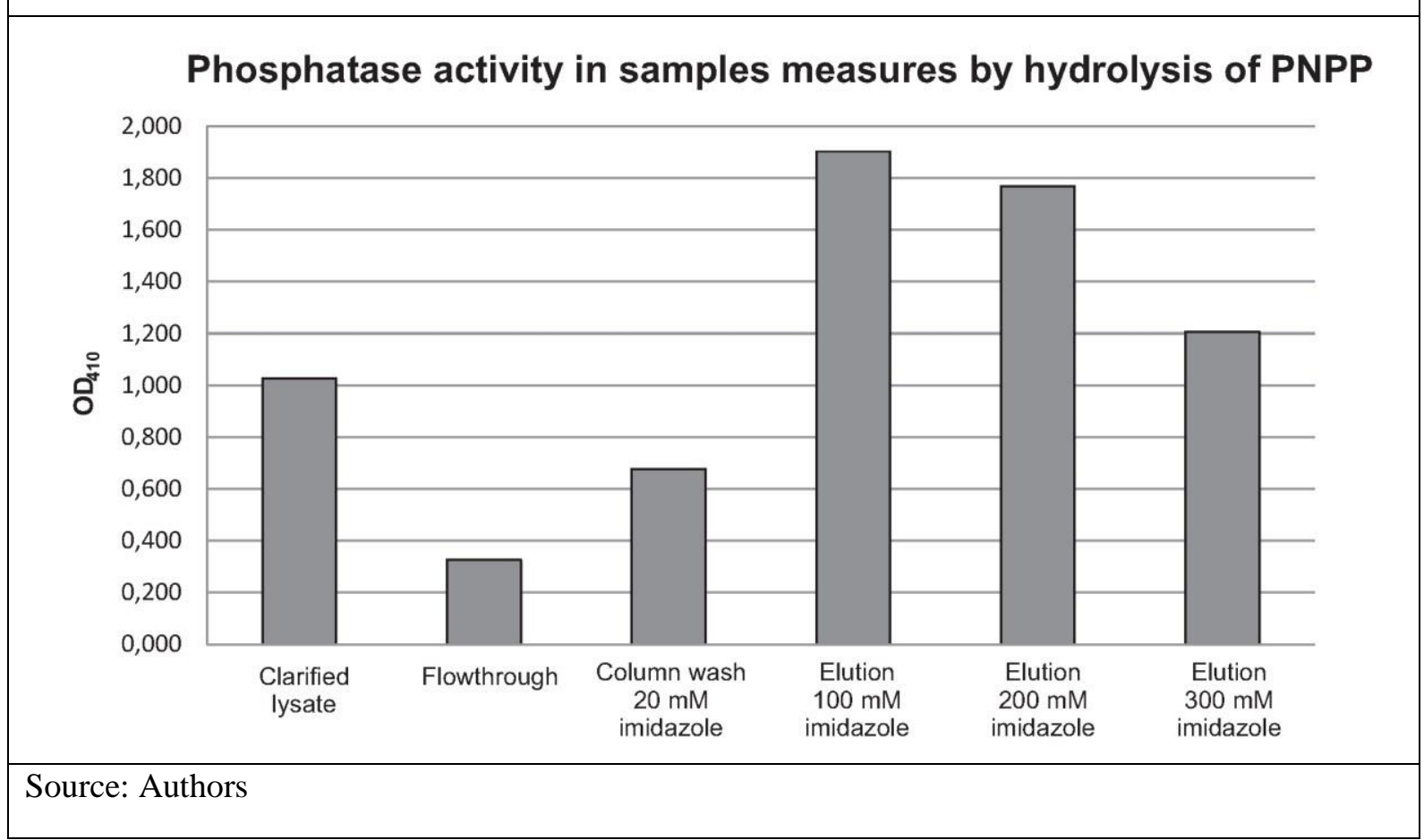


Figure 5: Activity of the recombinant phytase Nov9x on sodium phytate. Reaction of enzymatic hydrolysis of phytate performed at various temperatures in the range $30^{\circ} \mathrm{C}-80^{\circ} \mathrm{C}$.

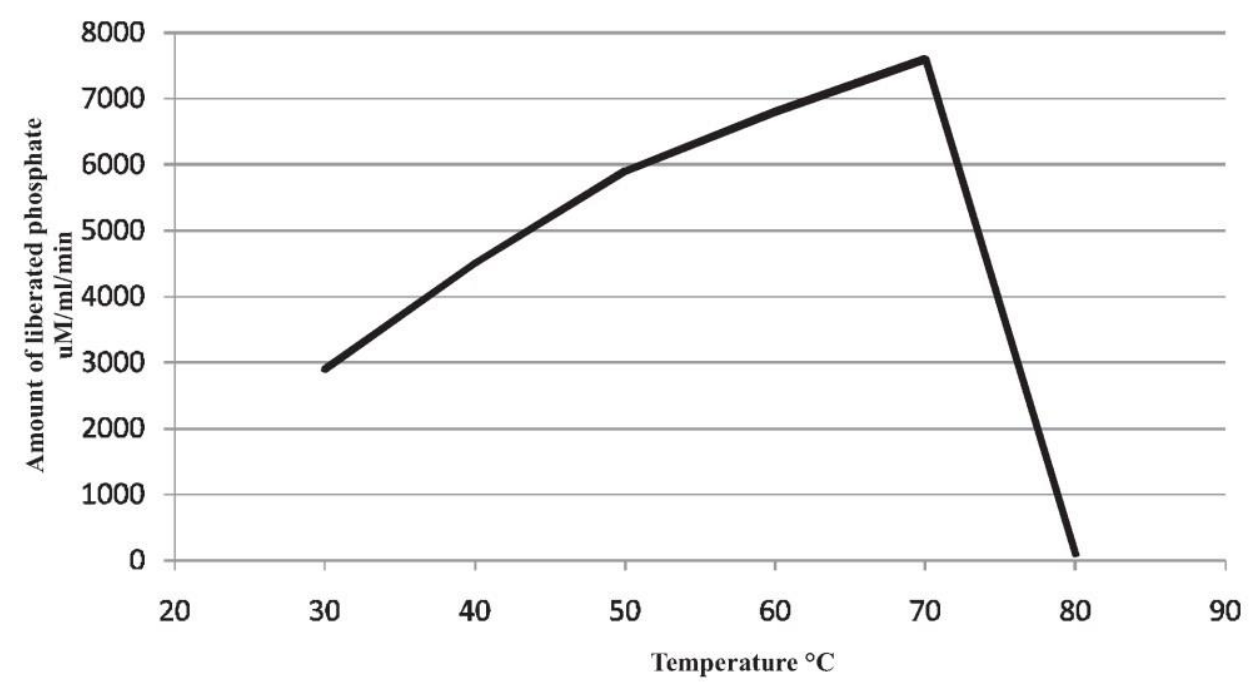

Source: Authors

\section{Conclusion}

Industrially produced phytases are in high demand in the modern animal farming where they are used as feed additives. Phytases are added to animal diets to improve utilization of phosphorus from plantderived components. Because of technological considerations, feed phytases have to withstand elevated temperatures $\left(60-80^{\circ} \mathrm{C}\right)$, which are used during preparation of fodder. Significant success in development of engineered thermotolerantphytases was achieved by the method of directed evolution, which comprises repeating rounds of an in vitro mutagenesis and selection of best enzymes by highthouroughput screening (Garret et al., 2004). Phytase Nov9x is a product of an exhaustive mutagenesis of the highly active E.coliphytaseAppA. The Nov9x differs from the parental enzyme AppA by eight amino acid substitutions. The Nov9x is a generic name of the enzyme available on the market under brands Quantum Phytase (Syngenta Animal Nutrition, USA) and Quantum Blue Phytase (AB Vista, Germany). Nov9x withstands incubation for 1 hour at $62^{\circ} \mathrm{C}$ without a loss of activity and maintains $27 \%$ of initial activity after 10 minutes at $85^{\circ} \mathrm{C}$.

We synthesized gene encoding the phytase Nov9x, expressed the gene in E.coli, and used enzymatic reactions to confirm specific biochemical properties of the product. Gene and expression system described has a prospective utilization in the development of pilot industrial production of phytase in the country.

\section{References}

Harland, B. F., \& Morris, E. R. (1995). Phytate: a good or a bad food component. Nutrition Research, 15, 733-754. doi: 10.1016/0271-5317(95)00040-P

Selle, P. H., Ravindran, V., Caldwell, A., \& Bryden, W. L. (2000). Phytate and phytase: conse-quences for protein utilisation. Nutrition Research Reviews, 13, 255-278. doi: 10.1079/095442200108729098

Luo, H., Huang, H., Yang, P., Wang, Y., Yuan, T., Wu, N., Yao, B., \& Fan, Y. (2007). A novel phytaseappA from Citrobacteramalonaticus CGMCC 1696: gene cloning and overexpression in Pichiapastoris. Current Microbiology, 55, 185192. doi: $10.1007 / \mathrm{s} 00284-006-0586-4$

Konietzny, U., \& Greiner, R. (2002) Molecular and catalytic properties of phytase degrading enzymes (phytases). International Journal of Food Science \& Technology, 37, 791-812. doi: 10.1046/j.1365-2621.2002.00617.x

Liu, B. L., Rafiq, A., Tzeng, Y. M., \& Rob, A. (1998). The induction and characterization of phytase and beyond. Enzyme and Microbial Technology, 22, 415-424. doi: 10.1016/S0141-0229(97)00210-X 
Vohoura, A., \& Satyanarayana, T. (2003). Phytases: microbial sources, production, purification, and potential biotechnological applications. Critical Reviews in Biotechnology, 23, 29-60. doi: 10.1080/713609297

Mullaney, E. J., \& Ullah, A. H. (2003). The term phytase comprises several different classes of enzymes. Biochemical and Biophysical Research Communications, 312, 179-184. doi: 10.1016/j.bbrc.2003.09.176

Oh, B. C., Choi, W. C., Park, S., Kim, Y. O., \& Oh, T. K. (2004). Biochemical properties and sub-strate specificities of alkaline and histidine acid phytases. Applied Microbiology and Biotechnology, 63, 362-372. doi: 10.1007/s00253-003-1345-0

Wyss, M., Brugger, R., Kronenberger, A., Remy, R., Fimbel, R., Oesterhelt, G., Lehmann, M., \& van Loon, A.P. (1999). Biochemical characterization of fungal phytases (myo-inositol hexakisphosphatephosphohydrolases): catalytic properties. Applied Environmental Microbiology, 65, 367-373.

Garret, J. B., Kretz, K. A., O'Donoghue, E., Kerovuo, J., Kim, W., Barton, N. R., Hazlewood, G. P., \& Short, J. M. (2004). Enhancing the Thermal Tolerance and Gastric Performance of a Microbial Phytase for Use as a Phosphate-Mobilizing Monogastric-Feed Supplement. Applied Environmental Microbiology, 70(5), 3041-3046. doi: 10.1128/AEM.70.5.30413046.2004 